\title{
Human Homeostatic Control Matrix in Norm
}

\author{
Alexander G. Kruglov*, PhD, ScD; Valery N. Utkin; Alexander Yu. Vasilyev, PhD, ScD; \\ Veronica A. Sherman \\ Central Research Institute of Radiation Diagnosis \\ Moscow, the Russian Federation
}

\begin{abstract}
We undertook our research to study and systemize the relationship between hemodynamics and biochemical parameters of arterial and venous blood in healthy people. Hemodynamic and biochemical characteristics were obtained through a probe by using catheterization in various vascular areas (aorta, brain, heart, lungs, and liver). Correlation and factor analyses were conducted to study the relationship between the obtained characteristics of the regional and systemic blood flow. Due to the nature of the correlation analysis, the significant $(\mathrm{p}<0.05)$ relation signs $(+, 0,-)$ without regard to their power were considered.

The obtained results suggested that there are sets of both intra-organ and system regulatory relationships between metabolic and hemodynamic characteristics. The complex of relationships among the studied parameters makes it possible to maintain the homeostatic equilibrium in the body. The psychophysiological control system includes the subsystems we described: 1) the cardiac-hepatic-pulmonary complex having properties of the metabolic and hemodynamic information field providing biological stability of the homeostasis; any significant imbalance of its elements triggers afferent information flows actualizing an afferent synthesis; 2) the mind forming gradient patterns of targeted behavior to eliminate metabolic imbalance, to achieve goals both as coded biological parameters and as the highest forms of behavior, to reach the ultimate goal: parametric, homeostatic equilibrium in the "biosphere" of the human body. By using the results of our research and the complex of dynamic relationships in human homeostasis, we built a homeostatic control matrix (HCM). (Int J Biomed. 2016;6(3):184-189.).
\end{abstract}

Key Words: homeostasis $\bullet$ control matrix $\bullet$ coronary sinus $\bullet$ cerebral blood flow $\bullet$ hepatic blood flow.

\section{Abbreviations}

Ao - aorta; AVDO2, arterial venous difference O2; BIF, bioinformatic flow; BUs, behavioral units; CC, cardiac cycle; CHA, common hepatic artery; CS, coronary sinus; CO, cardiac output; DP, diastolic blood pressure; Er, erythrocyte; EDP, end-diastolic pressure; F-n, fibrinogen; GIT, gastrointestinal tract; HPV, hepatic portal vein; HVWP, hepatic venous wedge pressure; IJV, internal jugular vein; IG, image of the goal; LV, left ventricle; MP, mean blood pressure; N, norm; PI, plasma; P-n, total protein; PP, pulse pressure; PT, pulmonary trunk; RA, right atrium; RV, right ventricle; RHV, right hepatic vein; Sin P, sigmoid sinus pressure; SS, sigmoid sinus; SP, systolic pressure; SVC, superior vena cava; SAH, stable arterial hypertension; SV, stroke volume.

\section{Objective}

The aim of the research was to systematize findings obtained during the analysis of the regional and systemic relationship between biochemical and hemodynamic characteristics; to build a principal diagram of stable

*Corresponding author: Alexander G. Kruglov, PhD, ScD. Central Research Institute of Radiation Diagnosis, Moscow, Russia. E-mail:krag48@mail.ru relationships between characteristics of metabolism, gas exchange, and hemodynamics; and to build a summarized matrix for relationships typical of homeostatic control in healthy humans.

\section{Materials and Methods}

All of the research through which we received the discussed results was conducted in the same laboratory and with the help of the same methods. The patients were in the 
supine position (in the perpendicular position to the vector of gravity when its influence in all parts of the venous system is equal). The data obtained by using catheterization performed with a probe show the blood pressure levels and biochemical parameters of the outflow from the studied organ (the wedging made it possible to obtain exchange and hemodynamic data directly from the target organs: the brain and the liver). We performed the catheterization of LV, Ao, IJV, SS, CS, SVC, RHV, RA, RV, and PT; during the procedure the pressure levels were recorded and blood samples were collected. The catheterization was performed by percutaneous puncture of the right femoral artery and the right femoral vein under local anesthesia, using the Seldinger technique. A vein dilator was used during the vein puncture. The catheter reached the aforesaid parts of the cardiovascular system. The arterial pressure values were recorded for the thoracic aorta. The studies were monitored by using radiography equipment.

The results for assessment were obtained from the studies conducted on apparently healthy people who were thoroughly examined in hospital before complex reconstructive maxillofacial surgery (these data have been represented in our early research papers, starting from 1976). The total number of the examined people was 60 (48 men and 12 women). The age of 52 of those people ranged from 20 to 45 , and 8 people were over 45 years old. In 18 (13 males and 5 females aged from 21 to 42 years) people, out of necessity, catheterization of CS (for estimation of biochemical and hemodynamic parameters in 6 persons) and right HV (for biochemical parameters in 11 people and hemodynamic parameters in 14 people) was conducted.

\section{Discussion}

When assessing the results, we took into consideration some principles of the general system theory, namely, regulation theory.

Homeostatic regulation is seen as a dynamic state, with changing adaptive oscillation of the parameters (regulatory subsystems) and maintenance of a flowing balance in the internal environment despite external changes. When external conditions change, the open self-regulating homeostatic system finds a multitude of functional stability parameters to restore the stability of the system. The range of physiological changes, within which the optimum life activity for the present environment persists, is seen as normal. To define boundaries of the normal range we used the confidence interval boundaries set for each parameter and value; these boundaries define the range within which the probability of the relevant parameter value is $95 \%$. We have investigated the values of the following parameters: content levels of plasma electrolytes $(\mathrm{K}, \mathrm{Na})$ and red blood cells (Er); blood gases $\left(\mathrm{pO}_{2}, \mathrm{pCO}_{2}\right)$; acid-base composition ( $\mathrm{pH}, \mathrm{SB})$; blood proteins: hemoglobin $(\mathrm{Hb}), \mathrm{F}-\mathrm{n}$, total protein $(\mathrm{P}-\mathrm{n})$; and arterial venous difference $\left(\mathrm{AVDO}_{2}\right)$ in some segments.

We have investigated the following parameters of central and systemic hemodynamics (expressed in $\mathrm{mmHg}$ ): $\mathrm{SP}, \mathrm{DP}$, PP, MP; EDP for LV and RV, and A/ X/ V/Y waves for RA.

To analyze the cerebral blood flow we opted for the hemodynamic pathway: $\mathrm{LV}-\mathrm{Ao}-\mathrm{SS}-\mathrm{IJV}-\mathrm{SVC}-\mathrm{RA}$. In addition to other relationships, we found (see HCM) that the active process of LV and Ao (systolic and pulse pressure) had no correlation relationships with the SinP pulse pressure, thus demonstrating absence of any relationships. The LV systolic pressure correlates negatively with the Sin P systolic, diastolic and mean pressure. Therefore, tin norm, Sin P development does not depend on the Ao pulse pressure. The negative correlation between LV and the SinP levels can be explained only by the structure that is located between the cranial cavity and extracranial vessels; the aortic flow makes the opening change. We assume that the above structure is represented by carotid siphons, which damp pressure values to the value equal to Ao mean pressure, which indicates that the integrated hydrodynamic system has moved into a stage of diastolic evolution (from MP to DP): Ao-cranial inlet vessels-Sin P. The positive correlations between the PT pressure levels, the RA pressure, and the Sin $\mathrm{P}$ indicate an existing relationship between the venous part of the cerebral blood flow and the hemodynamics of RA and PT, which create a pressure gradient of the blood flow through pulmonary capillaries (ie, boundaries with the external (gaseous) environment, where changes in the gradient and the gas composition of venous blood take place). The obtained data prove that rheological properties of blood and viscosity can be seen as a primarily regulated homeostasis parameter. We think that the integrated hydrodynamic space is one of the regulators of cerebral gas exchange, where the main factor is the minimum pressure along the path of the cerebral outflow - in RA. ${ }^{[1]}$

When comparing the respective values in healthy people and those suffering from SAH, we revealed their compliance with the averages values of the entire research range. Thus, we assumed that there were differences in interaction of biochemical substances and relationships between hemodynamic processes in healthy people compared to SAH patients. ${ }^{[2]}$ We compared the respective sets of correlation relationships between hemodynamic and biochemical characteristics at the inlet and outlet of the cerebral bloodflow system in healthy people and SAH patients. We revealed significant differences in the composition and quality of the sets of correlation relationships, including a lost relationship with end products of cerebral gas metabolism (O2, CO2, etc.) and a lost relationship between the cerebral blood flow and rheological characteristics of the cerebral blood outflow (general and plasma viscosity - F-n, P-n). SAH patients demonstrated inversion or loss of the entire set of Sin $\mathrm{P}$ hemodynamic relationships, and loss of relationships with the oncotic pressure, gas pressure, and blood viscosity parameters.

The results of the previous studies ${ }^{[3-8,1]}$ allow us to review and analyze cardiac hemodynamics as a "single entity" consisting of functional units: 1) "atrial unit" - RA and LA; 2) "aorto-pulmonary unit" - bulb of the aorta and PA; 3) "three-chamber unit" of ventricles, consisting of a) " the left chamber" (LV) and b) "the richt chamber" (RV) with blood outflow from the chambers into "aorto-pulmonary unit", and c) "spongy" venous chamber with blood outflow from the myocardium (during the united systole) through CS and Thebesian veins into the "atrial unit." During "united systole" 
of "three-chamber unit" of ventricles, the following blood volumes are moved: 1) LV and RV stroke volume into the "aorto-pulmonary unit"; 2) stroke volume from the "spongy" venous chamber into the "atrial unit" (these volumes constitute a united stroke volume of the "three-chamber unit"; and 3) blood inflow from SVC/IVC and pulmonary veins into the "atrial unit" during systolic/membrane blood suction and during the retraction of the tricuspid and mitral valves in the ventricular cavity during the blood expulsion from them. Thus, a united systole of "three-chamber unit" of ventricles is the basis for regulation: 1) the inflow (mobilization) of blood into the "atrial unit"; 2) systolic synchronization of hemodynamics in the "aorto-pulmonary" and "atrial" units; 3) intracardiac conditions of blood outflow from all chambers of the "threechamber unit" of the ventricles through the fixed rings of CS, truncus pulmonalis, and bulb of the aorta. The volume of the blood moved by ventricular myocardium during this period is more than a united stroke volume by the amount of venous blood mobilized to the "atrial unit."

$\mathrm{X}$-collapses in RA create a stable phase gradient of the venous drainage from the liver into RA. ${ }^{[1]}$ It remains positive (i.e., provides a constant outflow from the right HV into RA) throughout the united systole of the "ventricular unit," when the other phase gradients are zero or negative. It was shown that there is a synchronization of this flow with the same phases of flow outflow from the brain, lungs, and kidneys. As manifestations of a single process (myocardial contractility), all the indicators of a period of united systole change conjugate. We believe that this is the basis of the systolic regulation of venous outflow from the organs (including the liver) into the "atrial unit." Atrial contraction generates the " $\mathrm{A}$ " wave and not only pushes blood into the ventricles, but also disperses the shock wave reversely (against the blood flow). While we see the activity of ventricles as a quantum process, the retrograde propagation of the "A" wave is seen as a pre-quantization process. In other words, the activity of angions of functional elements (including metabolic processes) can be regulated by the central organ, the heart, through control wave signals, both down and up the blood flow.

A phase of the diastolic synchronization of intraorgan pressures, which takes place on the background of end-diastolic pressures in the ventricles, aorta, and pulmonary artery, occurs at open atrio-ventricular valves and the created united chambers: 1) "RV, RA, the veins of the great circle"; 2) "LV, LA, pulmonary veins." In this phase, there is a minimization of the differences between the levels and gradients of the pressures inside of the united chambers and between them. Our findings suggest ${ }^{[1]}$ that RA is a zone of unstable hydrodynamic balance within from 0 to $10 \mathrm{mmHg}$, having a number of fixed values (equal to pressure levels in pressure-bearing veins) synchronized with the phases of evolution of the cardiac cycle, which are the derived values from the dynamics of the cardiac cycle, as well as the threshold values for wave-control signals spreading to the exchange zone of organs, including the human heart. Our data allow to consider CS not only as a vessel for venous blood flow from the myocardium, but also as a channel of intracardiac regulation of LV function by the level of booster pressure in RA, and by the level of pressure in the united chamber (RV-RA) in phase of diastolic synchronization.

The wave impulse of the coronary sinus moves into the relaxing right atrium that has not reached its full diastolic volume and dissipates along the venous collectors. The topographic proximity, coincidence of the axes of the mouths of RHV and CS, and lack of influence of the venous damping of IVC lead to the situation where the right hepatic vein is the first and the closest recipient of a wave impulse from the coronary sinus of the heart.

The capacitance hepatic vessels characterized by negative relationships (see HCM) with the hemodynamic processes that we described earlier ${ }^{[1,3,10-16]}$ - the integrated chamber of RA-RV, RV-PT, vessels of inflow to RA, and CS - are outflow pathways, taking part in generation of blood flows in the venous heart. In norm, the anatomical structure of inflow and outflow pathways of the liver is built on the principle of minimizing the pressure fluctuations inside the liver parenchyma and constancy of liver functions. This structure aims to prevent the impact of the stress effect of the regurgitation from RA. This is achieved by hemodynamic and biochemical damping of arterial blood flow by the organs of the splanchnic system. Hemodynamic damping is provided by the evolutionarily determined pattern of origin and branching of trunks from the aorta. Each organ is characterized by differences in angles where trunks stem from the aorta. As the laminar flow has an elongated telescopic configuration where elements move at different speed, the structured layers, between which friction causes energy dissipation, are characterized by their own parameters. ${ }^{[17]}$

Thus, the angular differences in the ramifications of the vessels lead to a difference in the pressure levels (information) withdrawn from the spheroid of the pulse wave Ao, which causes the difference in information obtained by various organs. Structural changes in the conductivity of these pathways (for example, in SAH patients) cause malfunction of the compensatory mechanisms responsible for normal functioning.

In norm, the spherical dissipative wave structure of the pulsating flow generated by LV in Ao reaches all points of the microcirculatory bed in the human body before aortic valve closure. ${ }^{[18]}$ The impulse of the pulse wave adapted for each organ with the participation of its own arterial system, outpacing the formation of the bio-informatic flow (BIF) formed by $\mathrm{CC}$, prepares the exchange structures of the organ to receive this BIF.

The stemming pattern typical of trunks makes it possible that each organ receives the respective fixed segment of the pulse wave spheroid. In other words, the biochemical composition of blood is identical for all splanchnic organs, but the impulse of the pulse wave that precedes BIF is individual for each organ. A peripheral vascular resistance with reduced resistance in areas of increased metabolism (increased blood flow) is a mosaic information field $\left(1^{\text {st }}\right.$ feedback) for the source of the laminar arterial generator (heart), with change-informing and control signals in areas of increased blood flow (metabolism). Arterial inflow vessels transporting the laminar flow constitute a damping chamber responsible for stability of the organ's function. 


\section{Homeostatic Control Matrix}

\begin{tabular}{|c|c|c|c|c|c|c|c|c|c|c|c|c|c|c|c|c|c|c|c|c|c|c|c|c|c|c|c|c|c|c|c|c|c|c|c|c|}
\hline \multirow{2}{*}{\multicolumn{2}{|c|}{ Variable }} & \multicolumn{4}{|c|}{ Ao } & \multicolumn{5}{|c|}{ RA } & \multicolumn{2}{|c|}{$\mathrm{RV}$} & \multicolumn{2}{|c|}{ LV } & & & \multicolumn{4}{|c|}{ Sin $P$} & \multicolumn{4}{|c|}{ HVWP } & & RH & & & & C & $\mathrm{CS}$ & & & $\mathrm{P}^{\prime}$ & & \\
\hline & & $\mathrm{SP}$ & DP & & MP & $\mathrm{A}$ & $\mathrm{X}$ & & $\mathrm{Y} \mid \mathrm{I}$ & & EDI & $\mathrm{MP}$ & SP & PP & $\mathrm{CO}$ & $\mathrm{SV}$ & & $\mathrm{DP}$ & & MP & $\mathrm{SP}$ & $\mathrm{DP}$ & $\mathrm{PP}$ & MP & $\mathrm{SP}$ & & $\mathrm{PP}$ & MP & SP & $\mathrm{DP}$ & $\mathrm{PP}$ & MP & $\mathrm{SP}$ & & $\mathrm{PP} \mid \mathrm{I}$ & MP \\
\hline & $\mathrm{K}$ pl & & & & & - & - & - & - & $\mathrm{x}$ & $\mathrm{x}$ & $\mathrm{x}$ & $x$ & $x$ & $\mathrm{x}$ & $\mathrm{x}$ & + & & & & & & & & & & & & + & - & + & & & & & \\
\hline & $\mathrm{K}$ er & & & & & & & & & $\mathrm{X}$ & $\mathrm{x}$ & $\mathrm{x}$ & $\mathrm{x}$ & $\mathrm{x}$ & $\mathrm{x}$ & $\mathrm{x}$ & - & - & & - & & - & & - & & & + & - & + & & + & + & & & + & \\
\hline & $\mathrm{Na} \mathrm{pl}$ & & & & & & & & - & $\mathrm{x}$ & $\mathrm{x}$ & $\mathrm{x}$ & $\mathrm{x}$ & $\mathrm{x}$ & $\mathrm{x}$ & $\mathrm{x}$ & + & + & & & + & & & & & & & & - & - & - & - & & & & - \\
\hline Ao & $\mathrm{Na}$ er & & & & & - & - & - & - & $\mathrm{x}$ & $\mathrm{x}$ & $\mathrm{x}$ & $\mathrm{x}$ & $\mathrm{x}$ & $\mathrm{x}$ & $\mathrm{x}$ & - & & & & + & + & & & & & & & & - & + & & - & - & & - \\
\hline & $\mathrm{pH}$ & & & & & & & 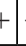 & + & $\mathrm{x}$ & $\mathrm{x}$ & $\mathrm{x}$ & $x$ & $\mathrm{x}$ & $\mathrm{x}$ & $\mathrm{x}$ & - & - & & - & & & - & & - & & - & - & - & & - & - & - & & & \\
\hline & $\mathrm{pCO}_{2}$ & & - & & - & - & & & - & $\mathrm{x}$ & $\mathrm{x}$ & $\mathrm{x}$ & $\mathrm{x}$ & $\mathrm{x}$ & $\mathrm{x}$ & $\mathrm{x}$ & & & & & & & + & + & + & & + & & & + & - & & & & & \\
\hline & SB & & - & & - & & & & & $\mathrm{x}$ & $\mathrm{x}$ & $\mathrm{x}$ & $\mathrm{x}$ & $\mathrm{x}$ & $\mathrm{x}$ & $\mathrm{x}$ & - & - & & - & + & + & & + & & & - & & - & & - & - & - & & - & \\
\hline & $\mathrm{pO}_{2}$ & & & & + & & & & & $\mathrm{x}$ & $\mathrm{x}$ & $\mathrm{x}$ & $\mathrm{x}$ & $\mathrm{x}$ & $\mathrm{x}$ & $\mathrm{x}$ & + & + & & + & & & & & & & & & & & & & & & & \\
\hline & $\mathrm{HbO}_{2}$ & & & & & & + & & + & $\mathrm{X}$ & $\mathrm{x}$ & $\mathrm{x}$ & $\mathrm{x}$ & $\mathrm{x}$ & $\mathrm{x}$ & $\mathrm{x}$ & & & & & & & & & & & + & & & + & - & & & & + & - \\
\hline & $\mathrm{Ht}$ & & & & & + & + & + & + & $x$ & $\mathrm{x}$ & $\mathrm{x}$ & $x$ & $\mathrm{x}$ & $\mathrm{x}$ & $\mathrm{x}$ & - & - & & - & $x$ & $x$ & $\mathrm{x}$ & $\mathrm{x}$ & $\mathrm{x}$ & $\mathrm{x}$ & $\mathrm{x}$ & $\mathrm{x}$ & $x$ & $\mathrm{x}$ & $\mathrm{x}$ & $\mathrm{x}$ & $\mathrm{x}$ & $\mathrm{x}$ & $\mathrm{x}$ & $\mathrm{x}$ \\
\hline & F-n & + & + & & & - & + & & - & $\mathrm{x}$ & $\mathrm{x}$ & $\mathrm{x}$ & $\mathrm{x}$ & $\mathrm{x}$ & $\mathrm{x}$ & $\mathrm{x}$ & - & - & & - & $x$ & $x$ & $\mathrm{x}$ & $\mathrm{X}$ & $\mathrm{x}$ & $\mathrm{x}$ & $\mathrm{x}$ & $\mathrm{x}$ & $x$ & $\mathrm{x}$ & $\mathrm{x}$ & $\mathrm{x}$ & $\mathrm{x}$ & $\mathrm{x}$ & $\mathrm{x}$ & $\mathrm{x}$ \\
\hline & P-n & & & & & & & & & $\mathrm{x}$ & $\mathrm{x}$ & $\mathrm{x}$ & $x$ & $\mathrm{x}$ & $\mathrm{x}$ & $\mathrm{x}$ & + & + & & + & $\mathrm{x}$ & $x$ & $\mathrm{x}$ & $\mathrm{x}$ & $\mathrm{x}$ & $\mathrm{x}$ & $\mathrm{x}$ & $\mathrm{x}$ & $x$ & $\mathrm{x}$ & $\mathrm{x}$ & $\mathrm{x}$ & $\mathrm{x}$ & $\mathrm{x}$ & $\mathrm{x}$ & $\mathrm{x}$ \\
\hline & H-b & & & & & & & + & & $\mathrm{x}$ & $\mathrm{x}$ & $\mathrm{x}$ & $x$ & $\mathrm{x}$ & $\mathrm{x}$ & $\mathrm{x}$ & - & - & & - & $\mathrm{x}$ & $x$ & $\mathrm{x}$ & $\mathrm{x}$ & $x$ & $\mathrm{x}$ & $x$ & $\mathrm{x}$ & $x$ & $\mathrm{x}$ & $\mathrm{x}$ & $\mathrm{x}$ & $\mathrm{x}$ & $\mathrm{x}$ & $\mathrm{x}$ & $\mathrm{x}$ \\
\hline & K pl & & & & & - & - & - & - & $\mathrm{x}$ & $\mathrm{x}$ & $\mathrm{x}$ & $x$ & $x$ & $\mathrm{x}$ & $\mathrm{x}$ & - & - & & - & & & - & - & & & & & + & - & + & - & & - & & \\
\hline & K er & & & & & & - & + & + & $\mathrm{x}$ & $\mathrm{x}$ & $\mathrm{x}$ & $x$ & $x$ & $x$ & $\mathrm{x}$ & & & & & & & - & - & & & & & + & - & + & - & & - & + & \\
\hline & $\mathrm{Na} \mathrm{pl}$ & & + & & + & & 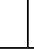 & - & - & $x$ & $\mathrm{x}$ & $\mathrm{x}$ & $\mathrm{x}$ & $\mathrm{x}$ & $\mathrm{x}$ & $\mathrm{x}$ & + & + & & + & - & - & & - & & & & & & & & & + & & + & \\
\hline $\mathrm{SS}$ & $\mathrm{Na}$ er & & & & & & & & - & $\mathrm{x}$ & $\mathrm{x}$ & $x$ & $x$ & $\mathrm{x}$ & $\mathrm{x}$ & $\mathrm{x}$ & & & & & - & - & & - & + & + & - & + & & - & + & - & & - & + & - \\
\hline & $\mathrm{pH}$ & & & & & - & & + & + & $\mathrm{x}$ & $\mathrm{X}$ & $\mathrm{x}$ & $x$ & $\mathrm{x}$ & $\mathrm{x}$ & $\mathrm{x}$ & - & - & & - & & & + & & & & & & - & + & - & + & & - & & - \\
\hline & $\mathrm{pCO}_{2}$ & & & & & & & & & $\mathrm{x}$ & $\mathrm{x}$ & $\mathrm{x}$ & $x$ & $x$ & $\mathrm{x}$ & $\mathrm{x}$ & & + & & & - & - & - & & & & + & - & 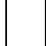 & & + & - & + & + & & + \\
\hline & SB & & & & - & & & + & & $\mathrm{X}$ & $\mathrm{x}$ & $\mathrm{x}$ & $x$ & $x$ & $\mathrm{x}$ & $\mathrm{x}$ & - & - & & - & & & + & + & & & & & - & + & - & + & & & & \\
\hline & $\mathrm{pO}_{2}$ & & & & & & - & - & - & $\mathrm{x}$ & $\mathrm{x}$ & $\mathrm{x}$ & $x$ & $\mathrm{x}$ & $x$ & $\mathrm{x}$ & & & & & & & & & & & & & & & & & & & & \\
\hline & $\mathrm{HbO}_{2}$ & & & & & - & - & - & - & $\mathrm{x}$ & $\mathrm{x}$ & $\mathrm{x}$ & $x$ & $\mathrm{x}$ & $\mathrm{x}$ & $\mathrm{x}$ & & & & & + & + & & + & & & + & & - & + & - & + & & & & - \\
\hline & $\mathrm{Ht}$ & & & & & & + & + & + & $\mathrm{x}$ & $\mathrm{x}$ & $\mathrm{x}$ & $x$ & $\mathrm{x}$ & $\mathrm{x}$ & $\mathrm{x}$ & & & & & $x$ & $x$ & $\mathrm{x}$ & $\mathrm{x}$ & $\mathrm{x}$ & $\mathrm{x}$ & $\mathrm{x}$ & $\mathrm{x}$ & $x$ & $\mathrm{x}$ & $\mathrm{x}$ & $\mathrm{x}$ & $\mathrm{x}$ & $\mathrm{x}$ & $\mathrm{x}$ & $\mathrm{X}$ \\
\hline & F-n & & + & - & & - & - & + & - & $\mathrm{x}$ & $\mathrm{x}$ & $\mathrm{x}$ & $x$ & $\mathrm{x}$ & $\mathrm{x}$ & $\mathrm{x}$ & - & - & & - & $x$ & $x$ & $x$ & $\mathrm{x}$ & $\mathrm{x}$ & $\mathrm{x}$ & $\mathrm{x}$ & $\mathrm{x}$ & $\mathrm{x}$ & $\mathrm{x}$ & $\mathrm{x}$ & $\mathrm{x}$ & $\mathrm{x}$ & $\mathrm{x}$ & $\mathrm{x}$ & $\mathrm{X}$ \\
\hline & P-n & & & & & & & & & $\mathrm{x}$ & $\mathrm{x}$ & $\mathrm{x}$ & $x$ & $\mathrm{x}$ & $\mathrm{x}$ & $\mathrm{x}$ & + & & & + & $\mathrm{X}$ & $x$ & $\mathrm{x}$ & $\mathrm{x}$ & $\mathrm{x}$ & $\mathrm{x}$ & $\mathrm{x}$ & $\mathrm{x}$ & $\mathrm{x}$ & $\mathrm{x}$ & $\mathrm{x}$ & $\mathrm{x}$ & $\mathrm{x}$ & $\mathrm{x}$ & $\mathrm{x}$ & $\mathrm{X}$ \\
\hline & H-b & & & & & & - & & - & $\mathrm{x}$ & $\mathrm{x}$ & $\mathrm{x}$ & $x$ & $\mathrm{x}$ & $\mathrm{x}$ & $\mathrm{x}$ & - & - & & - & $\mathrm{x}$ & $x$ & $x$ & $\mathrm{x}$ & $\mathrm{x}$ & $\mathrm{x}$ & $\mathrm{x}$ & $\mathrm{x}$ & $x$ & $\mathrm{x}$ & $\mathrm{x}$ & $\mathrm{x}$ & $\mathrm{x}$ & $x$ & $\mathrm{X}$ & $\mathrm{X}$ \\
\hline & SP & & & & + & - & + & & & + & & + & - & - & - & & $x$ & $x$ & $x$ & $\mathrm{x}$ & - & - & - & - & - & - & + & - & + & - & + & - & + & & + & \\
\hline & DP & & + & & + & & + & & & + & & + & - & - & - & & $\mathrm{x}$ & $\mathrm{x}$ & $x$ & $\mathrm{x}$ & - & - & - & - & & & & & + & - & + & - & + & & + & + \\
\hline & PP & & - & & & & - & & & & + & & & & & & $\mathrm{x}$ & $x$ & $x$ & $\mathrm{x}$ & - & - & - & - & - & - & & - & - & + & - & + & & - & + & - \\
\hline & MP & & & & + & & + & & + & + & - & + & - & - & - & - & $x$ & $x$ & $x$ & $\mathrm{x}$ & - & - & - & - & - & - & + & - & + & - & + & - & + & & + & \\
\hline & SP & & - & + & - & - & - & - & - & - & - & + & $x$ & $\mathrm{x}$ & $\mathrm{x}$ & $x$ & $\mathrm{x}$ & $x$ & $x$ & $\mathrm{x}$ & $x$ & $x$ & $x$ & $\mathrm{X}$ & + & + & + & + & - & & - & - & & & & - \\
\hline & DP & & - & + & - & - & - & - & - & - & - & + & $x$ & $x$ & $x$ & $\mathrm{x}$ & $\mathrm{x}$ & $x$ & $x$ & $\mathrm{x}$ & $x$ & $\mathrm{x}$ & $\mathrm{x}$ & $\mathrm{X}$ & + & + & & + & - & & - & - & & & & - \\
\hline & PP & & & & & & & - & - & & + & + & $x$ & $\mathrm{x}$ & $\mathrm{x}$ & $x$ & $x$ & $x$ & $x$ & $\mathrm{x}$ & $x$ & $x$ & $\mathrm{x}$ & $\mathrm{x}$ & & - & & & 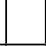 & + & - & + & & & & + \\
\hline & MP & & - & + & - & - & - & - & - & - & - & + & $x$ & $x$ & $\mathrm{x}$ & $\mathrm{x}$ & $x$ & $x$ & $x$ & $x$ & $x$ & $x$ & $x$ & $\mathrm{x}$ & + & + & & + & - & & - & - & & & & - \\
\hline & SP & + & & + & & + & + & & - & + & - & + & $x$ & $\mathrm{x}$ & $\mathrm{x}$ & $\mathrm{x}$ & $x$ & $x$ & $x$ & $\mathrm{x}$ & $\mathrm{x}$ & $\mathrm{x}$ & $x$ & $\mathrm{x}$ & $\mathrm{x}$ & $\mathrm{x}$ & $\mathrm{X}$ & $\mathrm{x}$ & - & & - & - & & & + & \\
\hline $\mathrm{RVH}$ & DP & & & + & & - & + & & & & - & & $x$ & $\mathrm{x}$ & $\mathrm{x}$ & $\mathrm{x}$ & $x$ & $\mathrm{x}$ & $x$ & $\mathrm{x}$ & $\mathrm{x}$ & $x$ & $\mathrm{x}$ & $\mathrm{x}$ & $\mathrm{x}$ & $\mathrm{x}$ & $\mathrm{X}$ & $\mathrm{x}$ & - & & - & - & & & + & \\
\hline & PP & + & & & + & + & + & + & & & & & $x$ & $\mathrm{x}$ & $\mathrm{x}$ & $\mathrm{x}$ & $\mathrm{x}$ & $\mathrm{x}$ & $\mathrm{x}$ & $\mathrm{x}$ & $\mathrm{x}$ & $\mathrm{x}$ & $\mathrm{x}$ & $\mathrm{x}$ & $\mathrm{x}$ & $\mathrm{x}$ & $\mathrm{x}$ & $\mathrm{x}$ & + & + & & + & & & & \\
\hline & MP & + & & + & & & + & - & + & $=$ & - & & $\mathrm{x}$ & $\mathrm{x}$ & $\mathrm{x}$ & $\mathrm{x}$ & $x$ & $\mathrm{x}$ & $x$ & $\mathrm{x}$ & $\mathrm{x}$ & $\mathrm{x}$ & $\mathrm{x}$ & $\mathrm{x}$ & $\mathrm{x}$ & $\mathrm{x}$ & $\mathrm{x}$ & $\mathrm{x}$ & - & & - & - & & & + & \\
\hline & SP & + & + & - & + & + & + & + & + & + & + & - & $x$ & $\mathrm{x}$ & $\mathrm{x}$ & $\mathrm{x}$ & $\mathrm{x}$ & $\mathrm{x}$ & $x$ & $\mathrm{x}$ & $\mathrm{x}$ & $\mathrm{x}$ & $\mathrm{x}$ & $\mathrm{x}$ & $\mathrm{x}$ & $\mathrm{x}$ & $\mathrm{x}$ & $\mathrm{x}$ & $x$ & $\mathrm{x}$ & $\mathrm{x}$ & $\mathrm{x}$ & + & + & + & + \\
\hline cs & DP & & + & - & + & + & + & + & + & + & + & - & $x$ & $\mathrm{x}$ & $\mathrm{x}$ & $x$ & $\mathrm{x}$ & $x$ & $x$ & $x$ & $x$ & $x$ & $x$ & $\mathrm{x}$ & $\mathrm{x}$ & $\mathrm{x}$ & $\mathrm{X}$ & $\mathrm{x}$ & $x$ & $\mathrm{x}$ & $\mathrm{x}$ & $\mathrm{x}$ & & + & - & \\
\hline & PP & & + & - & & & & & + & & & - & $x$ & $\mathrm{x}$ & $\mathrm{x}$ & $\mathrm{x}$ & $x$ & $x$ & $x$ & $\mathrm{x}$ & $\mathrm{X}$ & $\mathrm{x}$ & $\mathrm{x}$ & $\mathrm{x}$ & $\mathrm{x}$ & $\mathrm{x}$ & $\mathrm{x}$ & $\mathrm{x}$ & $\mathrm{x}$ & $\mathrm{x}$ & $\mathrm{x}$ & $\mathrm{x}$ & + & & + & + \\
\hline & MP & + & + & - & + & + & + & + & + & + & + & - & $x$ & $\mathrm{x}$ & $\mathrm{x}$ & $\mathrm{x}$ & $\mathrm{x}$ & $\mathrm{x}$ & $\mathrm{x}$ & $\mathrm{x}$ & $\mathrm{x}$ & $\mathrm{x}$ & $x$ & $\mathrm{x}$ & $\mathrm{x}$ & $\mathrm{x}$ & $x$ & $\mathrm{x}$ & $\mathrm{x}$ & $\mathrm{x}$ & $\mathrm{x}$ & $\mathrm{x}$ & + & + & & \\
\hline & SP & + & + & & + & + & + & + & + & + & + & & $x$ & $\mathrm{x}$ & $\mathrm{x}$ & $\mathrm{x}$ & $\mathrm{x}$ & $\mathrm{x}$ & $\mathrm{X}$ & $\mathrm{x}$ & $x$ & $x$ & $\mathrm{x}$ & $\mathrm{x}$ & $\mathrm{x}$ & $\mathrm{x}$ & $\mathrm{x}$ & $x$ & $\mathrm{x}$ & $\mathrm{x}$ & $\mathrm{x}$ & $\mathrm{x}$ & $\mathrm{x}$ & $\mathrm{x}$ & $\mathrm{x}$ & $\mathrm{X}$ \\
\hline Pl & DP & & + & & + & & & & & & + & & $x$ & $x$ & $\mathrm{x}$ & $\mathrm{x}$ & $x$ & $x$ & $x$ & $\mathrm{x}$ & $\mathrm{x}$ & $x$ & $\mathrm{x}$ & $\mathrm{x}$ & $\mathrm{x}$ & $\mathrm{x}$ & $\mathrm{x}$ & $\mathrm{x}$ & $x$ & $\mathrm{x}$ & $\mathrm{x}$ & $\mathrm{x}$ & $\mathrm{x}$ & $\mathrm{x}$ & $\mathrm{x}$ & $\mathrm{x}$ \\
\hline & PP & + & & & + & + & & & & + & & & $x$ & $x$ & $x$ & $x$ & $x$ & $x$ & $x$ & $x$ & $x$ & $\mathrm{x}$ & $x$ & $x$ & $x$ & $\mathrm{x}$ & $x$ & $x$ & $x$ & $x$ & $x$ & $x$ & $\mathrm{x}$ & $x$ & $x$ & $x$ \\
\hline & MP & + & + & & + & + & + & + & + & + & + & + & $x$ & $\mathrm{x}$ & $\mathrm{x}$ & $\mathrm{x}$ & $\mathrm{x}$ & $\mathrm{x}$ & $x$ & $x$ & $x$ & $\mathrm{x}$ & $\mathrm{x}$ & $\mathrm{x}$ & $\mathrm{x}$ & $\mathrm{x}$ & $\mathrm{x}$ & $\mathrm{x}$ & $\mathrm{x}$ & $\mathrm{x}$ & $\mathrm{x}$ & $\mathrm{x}$ & $\mathrm{x}$ & $\mathrm{x}$ & $\mathrm{x}$ & $\mathrm{x}$ \\
\hline
\end{tabular}


Biochemical damping of venous blood along the inflow pathways to the liver from splanchnic organs was described earlier. The capacitance venous vessels of the liver are communication channels between the evolutionarily younger (lungs) and older (splanchnic organs) functional systems of the human body. The hepatic venous circulation provides interference of the information and biochemical relationships between the body and the external environment through the venous outflow from GIT (the zone preceding the liver) and arterial flow - CHA (an indicator of aortic hemodynamics and gas exchange in lungs). It results in an integrated BIF of venous outflow from the liver (whose "thesaurus" includes the information volumes of organs preceding the liver), which has uniform hemodynamic and biochemical parameters and interacts with the blood flow of RA and all phases of $\mathrm{CC}$ and hemodynamics in IVC/SVC pools and CS (see HCM).

In changeable conditions of the external (gaseous) environment, homeostasis of the open self-regulating system (the liquid medium) can be maintained only by changes in the interaction of such systems as a human being and the external environment through different patterns of adaptive behavior. In the theory of Type 2 functional systems, ${ }^{[19]}$ the integrative BUs that maintain homeostasis through changes in behavior provide functioning, retaining and subsequent elimination of the ideal IG that is developed as a product of the afferent synthesis. BUs constitute structurally identical, regular sequences, which do not depend on any content of IG and final outcome. They have characteristics of bijective reflection, in which they retain the coded structure of the object as an information matrix. Having no dimensions we are aware of, except for a time dimension, IG can include any possible and conceivable type of space and dimension, thus giving grounds for the assumption that they exist (or can be developed) in human mental formations in a compact (potential) form and can be decoded by the operating mental systems (thinking, imagination, etc.). BUs participate in generating, developing and retaining an ideal $\mathrm{IG}$, which is a spatiotemporal entity of activated neural formations of the brain.

We think that the BU afferent stage starts when there is significant imbalance of parameters, misalignment in the system of metabolic, psychological (including social) relationships or, in other words, when there is any deviation from the boundaries of the "normal zone". For metabolism, a deviation from the upper/lower bounds of the normal zone to the level of the suprathreshold sensitivity of the receptors (the first signal system) is involved; ${ }^{[2,20]}$ for structures of the psychological and social spectra, involvement is to the level of "cognized-not-cognized" and "acceptable-not-acceptable" (the second signal system). The distinguishing characteristic of "living beings" is their responsiveness to any disturbance in the homeostatic balance, to outright imbalance, i.e. the selective response to the object of an actual need. The need, being the most significant disposition of the motive, constitutes "an impelling force, a cause of the behavior" "21] and triggers activation of integrative units of behavior (targeted behavior). We intentionally simplify the hierarchy and structure of psychosomatic relationships, and think that the afferent information flow initiated by homeostatic imbalance actualizes an afferent synthesis and generates the image of a future result - the key component of the intelligent regulatory process a coded IG, which is retained until the goal is reached: the imbalance is rectified, the need is satisfied, the motive loses its effect, and the homeostatic equilibrium (of metabolic and mental nature) is recovered. In our other works we have described our perception of the development stages of adaptive self-regulation, including creation of motivating (reachable and non-reachable) IGs in the behavioral continuum, as well as subjective time and motivation gradient. ${ }^{[20,22]}$

We see goal-setting caused by a misalignment of the system as a continuous reflection from one space (objective reality) to another (mental structures of reflection), which has different dimensional, temporal, spatial, and other categories. The mental structures of the goal image are further projected into the "external world" through targeted behavior. This results in a correlation between the sets where the near points of reference turn into near points of values. IG has a dualistic nature; it is both an ideal image of the future and a prerequisite to initiating targeted behavior. The synthetized and retained IG includes basic forms of advanced reflection: forecasting and goal-setting. Note that forecasting is advanced modeling of objective sequences, while goal-setting implies involvement of the subject in a targeted activity. Despite these differences, the interference of these forms of advanced reflection is essential for selection of the available parametric information, control signals and, therefore, tactics and strategy of adaptive behavior, the main outcome of which is the achieved homeostatic equilibrium. We define the goal image as an active distributed system capable of spontaneously creating, in response to the information contained in IG, static and spatially heterogeneous structures facilitating adaptive behavior (for example, morphogenesis in a fertilized egg). The result of a specific mental activity (specific human "need"), creating an "artistic image," is that it becomes the "insight," [22] (ie, completion of the unconscious formation (afferent synthesis) of the "artistic image," or IG). The subsequent projection, embodied in visualized forms, cumulatively produces fragments of the cultural environment. As an IG biophysical "marker," we present a hemodynamic, scalar gradient of the fluent venousliquor pressure (with morphophysiological characteristics) in the exchange fields of actualized neural circuits. ${ }^{[20]}$

As we do not have our own data, we do not discuss participation of the nervous system, endocrine system, and other organs in homeostatic regulation, assuming that they are included in the system of psychophysiological regulation as it is described in present-day studies.

\section{Conclusion}

In sum, the studied organs of the healthy human body have sets of intra-organ regulatory relationships between metabolic and hemodynamic characteristics as well as sets of inter-organ relationships between parameters of systemic and regional hemodynamics. The complex of these relationships, which is given in HCM, makes it possible to maintain the homeostatic equilibrium in the body. The highest hierarchical level of the homeostatic regulation of the human being, where 
the permanence of some parameters is maintained through changes in other parameters, is a system of psychophysiological control and regulation of permanently existing parameters of the internal liquid medium in the conditions characterized by changeable parameters of the external (gaseous) environment. The imbalance of metabolic characteristics prior to the level of suprathreshold sensitivity of receptors (for the psychological and social range prior to the level of perceived/not perceived, acceptable/not acceptable) triggers actualization of needs and adaptive patterns of behavior. The psychophysiological control system includes the subsystems we described: 1) the cardiac-hepatic-pulmonary complex having properties of the metabolic and hemodynamic information field providing biological stability of the homeostasis; any significant imbalance of its elements triggers afferent information flows actualizing an afferent synthesis; 2) the mind forming gradient patterns of targeted behavior to eliminate metabolic imbalance, to achieve goals both as coded biological parameters and as the highest forms of behavior, to reach the ultimate goal: parametric, homeostatic equilibrium in the "biosphere" of the human body.

\section{Competing interests}

The authors declare that they have no competing interests.

\section{References}

1. Kruglov AG, Gebel GY, Utkin VN, Vasiliev AY, Sherman VA. Dynamic Networks of Human Homeostasis Control in Norm (Part 1). Int J Biomed. 2016; 6(2):101-105.

2. Kruglov AG, Gebel GYa, Vasilyev AY. Impact of IntraExtracranial Hemodynamics on Cerebral Ischemia by Arterial Hypertension (Part 1-2). Int J Biomed. 2012;2(2):96-101.

3. Utkin VN, Dasaev AN, Gebel GYa, Kruglov AG, Lilloson AA, Golostenova LM. The venous circulation of the liver at the stable hypertension (arterial and pulmonary) and in healthy individuals. Proceedings of the All-Union Congress of Neurosurgeons. Yaroslavl, 1990:19.[in Russian].

4. Gebel GYa, Utkin VN, Dasaev AN, Kruglov AG, Golostenova LM, Ignatov NG, et al. Pressure (general, gas and hemodynamic) in human heart vessels ( the coronary sinus, the pulmonary artery, aortic bulb) in the norm. Proceedings of the simposium "Clinic, diagnosis and treatment in the Russian Federation”. Moscow, 1993:25-29. [in Russian].

5. Gebel GYa, Golostenova LM, Dasaev AN, Utkin VN, Kruglov AG, Bagdatyev VE, et al. Blood composition of the coronary sinus in healthy people. Proceedings of the 7th Russian Symposium "Ecological and physiological problems of adaptation." Moscow, 26-28 April 1994: 59-60.[in Russian]. 6. Gebel GYa, Kruglov AG, Golostenova LM, Dasaev AN, Utkin VN, Bagdatjev VE, et al. About function of the "ventricular block" in human heart. Proceedings of the 2nd World congress on pediatric intensive care, Rotterdam,1996; 22(Suppl 2):163.

7. Gebel G Ya, Kruglov AG, Golostenova LM, Dasaev AN, Utkin VN, Bagdatjev VE, et al. The function of the "ventricular block" in human heart. Intensive care for the young. Acta Anaesthesiology Scandinavica, October 1996..

8. Gebel GYa, Kruglov AG, Utkin VN, Golostenova LM, Dasaev AN, Bagdatyev VE, et al. The analysis of heart activity as a "whole." Proceedings of the $1^{\text {st }}$ Congress of Heart Association of CIS countries. Moscow, 1997: 51. [in Russian]. 9. Gebel GYa, Kruglov AG, Utkin VN, Golostenova LM, Dasaev AN, Ignatov NG, Suvorov SG. Summary gas pressure (pO2+pCO2) in blood of sinus coronarius, arteria pulmonalis and the aorta in healthy adult humans. Proceedings of the $10 \mathrm{t}^{\mathrm{h}}$ International Congress on Cardiovascular Pharmacotherapy. Japan, Kioto, 2001; 15(1):394..

10. Gebel GYa, Dasaev AN, Belichenko IA, Kruglov AG, Gudenko VV, Utkin VN. Intracranial venous pressure in the norm and arterial hypertension. Abstracts of the 7th Union Conference on Space and aerospace medicine. Kaluga,1982. [in Russian].

11. Gebel GYa, Kruglov AG, Utkin VN, Bagdatyev VE, Dasaev AN, Golostenova LM . Importance of the human coronary sinus in the norm (synchronization in the circulatory system). Reports of the 10th Conference on Space Biology and Aerospace Medicine. Moscow; June 7-10, 1994.56-57.[in Russian].

12. Gebel GYa, Kruglov AG, Utkin VN, Golostenova LM, Dasaev AN, Ignatov NG, Suvorov SG. Venous hemodynamics in human liver. Russian J Gastroenterol Hepatol Coloproctol. 1997; 5(Suppl 4):139-41. [in Russian].

13. Gebel G Ya, Kruglov AG, Utkin VN, Golostenova LM, Dasaev AN, Ignatov NG, Suvorov SG. The assessment of the functional "ventricular block" in health individuals. The 3th World congress of pediatric cardiology and cardiac surgery. Canada, 2001:439.

14. Gebel GY, Golostenova LM, Kruglov AG, Dasaev AN, Utkin VN, Bagdatyev VE, et al. Hemodynamic and Gas Characteristics in Normal Human Heart Vessels - Coronary Sinus, Pulmonary Artery and Aorta. $9^{\text {Th }}$ European Congress of Anaesthesiology. Jerusalem, Israel. October 2-7, 1994:476. 15. Gebel GYa, Dasaev AN, Pravetsky NB, Khilkin AM, Vyachkileva NK, Yuryev YuP, et al. The state of the parameters of hemodynamic and liver gas exchange in the association with the biochemical composition of arterial blood in patients with hypertension. Proceedings of the "The conference of the 4th Management of the Ministry of Health." Moscow; 1977:28-29. [in Russian].

16. Utkin VN, Dasaev AN, Gebel GAYa, Kruglov AG, Lilloson AA, Golostenova LM. The venous circulation of the liver at the stable hypertensions (arterial hypertension and pulmonary hypertension) and in healthy individuals. Proceedings of the All-Union Congress of Neurosurgeons. Yaroslavl, 1990:19. [in Russian].

17. Landau LD, Lifshitz EM. Theoretical physics. Hydrodynamics. M.: "Nauka"; 1986, 736 pp. [in Russian].

18. Lightfoot A. Transport phenomena in live systems. Biomedical aspects of momentum and mass transport. M.: Mir; 1977, 520 pp. [in Russian].

19. Anochin PK. Philosophical aspects of the theory of the functional systems. Moscow: Science; 1978, 399 pp. [in Russian].

20. Kruglov AG, Vasilyev AY, Sherman VA. Human dynamic homeostasis control matrix in the norm with psychophysiological aspects. New York: IMRDC; 2016, 55 pp. 21. Shvyrkov VB. Introduction to objective psychology. Neuronal basics of psychics. Moscow: Psychology Institute of RAS (Russian Academy of Sciences); 1995, 162 pp. [in Russian].

22. Kruglov AG. A Mythologem as a Determinant of GoalDirected Behavior. Int J Biomed. 2015;5(4):231-4. 